\title{
Role of bimaxillary surgery in treatment of high respiratory obstructive sleep apnea syndrome
}

\author{
Ashraf MS Ghanem \\ From IBRA Conference on Surgery of the Head, 6th International Orthognathic Surgery Forum \\ Interlaken, Switzerland. 14-15 February 2014
}

High respiratory obstructive sleep apnea syndrome (OSAS) is a potentially disabling condition, characterized by excessive daytime sleepiness, disruptive snoring, recurrent episodes of apnea (or hypopnea) and nocturnal hypoxemia. It is a sign of increased pharyngeal airflow resistance (apnea hypopnea index (AHI $\geq 5$ ).

Twelve patients suffering from mild-to-severe OSAS received CPAP treatment and the ANB angle of their cephalometric analysis is $<1$ degree and therefore, diagnosed as a hidden maxillo-mandibular skeletal deformity.

In this study, an innovative technique is designed to modify the maxillary mandibular advancement (MMA) surgical principle method and applied to treat these cases. While tracheal, nasal and uvulo-palatal tissues were not collapsing and obstructing the upper airway region, skeletal advancements was used to create and enlarge tongue room space resulting a patent posterior airway space (PAS). Digitally measured diameter at the epiglottis region in oro-pharyngeal airway space, was implemented, assuming a cylindrical model, to determine the total air volume change.

Results showed a marked positive air flow gain (approximately $1.1 \pm 0.2 \mathrm{~cm}^{3} ; 12$ months postoperative) with statistical significant differences $(\mathrm{p}<0.01)$. Thus it has been concluded that MMA is very useful in managing severe class III skeletal deformity having OSAS via increasing the total air column volume gain in the upper oro-pharyngeal airway space at the epiglottis region. It may, therefore, be advocated that it could be considered as a standard surgical treatment after failure of CPAP existed.

Published: 12 December 2014

Department of Oral and Maxillofacial Surgery, Faculty of Dentistry, Minia University, Minya, Egypt

C Biomed Central

(0) 2014 Ghanem; licensee BioMed Central Ltd. This is an Open Access article distributed under the terms of the Creative Commons Attribution License (http://creativecommons.org/licenses/by/4.0), which permits unrestricted use, distribution, and reproduction in any medium, provided the original work is properly cited. The Creative Commons Public Domain Dedication waiver (http:// creativecommons.org/publicdomain/zero/1.0/) applies to the data made available in this article, unless otherwise stated.
doi:10.1186/1746-160X-10-S1-O9

Cite this article as: Ghanem: Role of bimaxillary surgery in treatment of high respiratory obstructive sleep apnea syndrome. Head and Face Medicine 2014 10(Suppl 1):09.

Submit your next manuscript to BioMed Central and take full advantage of:

- Convenient online submission

- Thorough peer review

- No space constraints or color figure charges

- Immediate publication on acceptance

- Inclusion in PubMed, CAS, Scopus and Google Scholar

- Research which is freely available for redistribution Submit your manuscript at
www.biomedcentral.com/submit C Biomed Central 